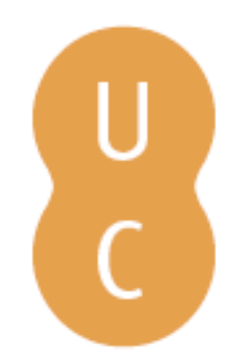

\title{
pommalina
}

\section{Past and present fire regimes in temperate forest zone of lowland Central Europe}

Autor(es): $\quad$ Zin, Ewa; Niklasson, Mats; Szczygie, Ryszard

Publicado por: Imprensa da Universidade de Coimbra

URL

persistente: $\quad$ URI:http://hdl.handle.net/10316.2/34199

DOI: $\quad$ DOI:http://dx.doi.org/10.14195/978-989-26-0884-6_66

Accessed : $\quad$ 26-Apr-2023 01:28:30

A navegação consulta e descarregamento dos títulos inseridos nas Bibliotecas Digitais UC Digitalis, UC Pombalina e UC Impactum, pressupõem a aceitação plena e sem reservas dos Termos e Condições de Uso destas Bibliotecas Digitais, disponíveis em https://digitalis.uc.pt/pt-pt/termos.

Conforme exposto nos referidos Termos e Condições de Uso, o descarregamento de títulos de acesso restrito requer uma licença válida de autorização devendo o utilizador aceder ao(s) documento(s) a partir de um endereço de IP da instituição detentora da supramencionada licença.

Ao utilizador é apenas permitido o descarregamento para uso pessoal, pelo que o emprego do(s) título(s) descarregado(s) para outro fim, designadamente comercial, carece de autorização do respetivo autor ou editor da obra.

Na medida em que todas as obras da UC Digitalis se encontram protegidas pelo Código do Direito de Autor e Direitos Conexos e demais legislação aplicável, toda a cópia, parcial ou total, deste documento, nos casos em que é legalmente admitida, deverá conter ou fazer-se acompanhar por este aviso. 


\section{ADVANCES IN}

Forest Fire

\section{RESEARCH}

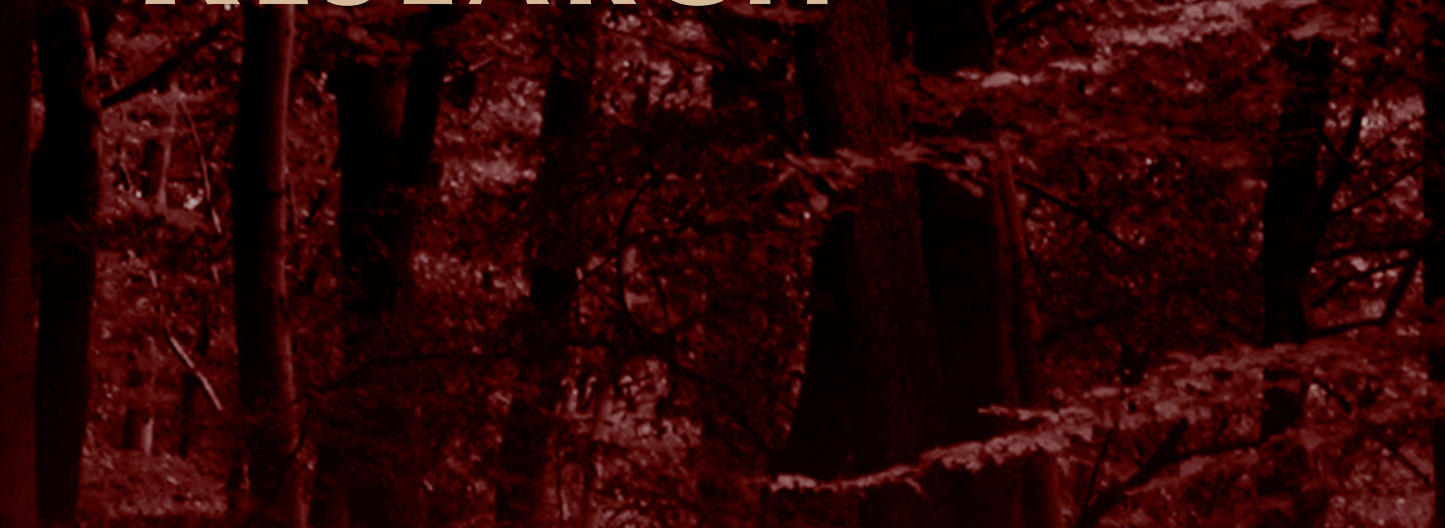

\section{DOMINGOS XAVIER VIEGAS}

\section{EDITOR}




\title{
Past and present fire regimes in temperate forest zone of lowland Central Europe
}

\author{
Ewa Zinª, , Mats Niklasson ${ }^{\mathrm{b}}$, Ryszard Szczygieł ${ }^{\mathrm{c}}$ \\ ${ }^{a}$ Forest Research Institute (IBL), Department of Natural Forests, ul. Park Dyrekcyjny 6, 17-230 \\ Białowieza,Poland,Ewa.Zin@slu.se,ezin@las.ibl.bialowieza.pl \\ ${ }^{b}$ Swedish University of Agricultural Sciences (SLU), Department of Southern Swedish Forest \\ Research Centre, P.O.Box 49, SE-23053 Alnarp,Sweden, Mats.Niklasson@slu.se \\ ${ }^{c}$ Forest Research Institute (IBL), Department of Forest Fire Protection, ul. Braci Leśnej 3, Sękocin \\ Stary,05-090 Raszyn, Poland, R.Szczygiel@ibles.waw.pl
}

\begin{abstract}
Fires in Central European lowland forests are nowadays numerous but efficiently suppressed and hence usually very small. Poland is one of the countries with highest annual number of forest fires in the region, with as many as 9-10 000 individual fire events per year (with record of 17000 fires in 2003), however of relatively limited size, with $0.5-0.95$ ha being mean values of area burned in a single forest fire. Main fire season in Poland lasts from March to September and is driven largely by weather conditions and litter humidity, with people being the dominant source of ignition. Active forest fire prevention and suppression is carried both by the regular fire services and State Forest Administration - the main forest manager in Poland due to the ownership structure of forest land in the country ( $>80 \%$ state-owned). In Białowieża Forest, one of the best preserved lowland forest ecosystems in temperate Europe fires happen at present rather incidental, alike in the rest of the country are effectively controlled and thereby affect very small areas ( $0.5 \mathrm{ha})$. However numerous stands with fire scarred trees, stumps and snags, especially in the conifer dominated areas, can be found; indicating substantial fire presence in the past. The first tree ring fire history records from that area evidenced frequent fires in Pinus sylvestris-dominated forests during the 17th up to early 19th centuries, with dramatic decrease in fire presence over the last $150+$ years, most likely linked to changes in human fire use and forest management. We conclude that there is a large need for fire history and fire ecology studies in Central Europe due to high population density and strong dominance of flammable conifers in forests of that region. Extended knowledge about past disturbance dynamics and reference conditions may be essential for future sustainable forest management and nature conservation throughout this part of European continent.
\end{abstract}

Keywords: annually burned area, Białowieża Forest, dendroecology, fire ecology, fire history, fire protection, fire scars, fire suppression, forest fires, forest fire statistics, mean annual number of fires, Pinus sylvestris, Poland, tree rings

\section{Introduction}

Fires in Central European lowland forests are nowadays numerous but efficiently suppressed and hence usually very small (Szczygieł et al. 2009a; Schmuck et al. 2011). However, that region has evidenced a significant rise in the number of forest fires in the recent decades (Szczygiel et al. 2008, $2009 a, b$ ), alike the whole European continent (Schelhaas et al. 2003).

Although fire has been proven to be one of the key elements of European lowland forest ecosystems during the Holocene (e.g. Hannon et al. 2000; Rösch 2000), the knowledge on fire ecology in that region is limited (Bradshaw et al. 1997; Hille 2006; Niklasson et al. 2010). Forest fires in that part of Europe are still associated with threat and large economic losses (Ubysz and Szczygieł 2002; Ubysz et al. 2006; Szczygieł et al. 2009a), which may impede the acceptance of fire as one of the important natural factors shaping forest structure and dynamics throughout the region (cf. Faliński 2001).

Given the significant share of fire-prone coniferous forests and the observed increase in fire activity throughout Central Europe, projected climate change and its possible influence on forest fire risk in 
the near future (Badeck et al. 2003; Schelhaas et al. 2003, 2010; Szczygieł et al. 2008, 2009a; SanMiguel-Ayanz et al. 2011), extended knowledge on the ecological role of fire in forest ecosystems of that region is valuable.

Poland is one of the largest countries in Central-Eastern Europe (Szczygieł et al. 2009a), with the total country area of approx. $312.7 \mathrm{th} . \mathrm{km}^{2}$ and total population of approx. 38.5 mill people, reflecting high population density of 123 people/ $\mathrm{km}^{2}$ (GUS 2014). Over 9 mill ha, accounting for ca. one third of the country area is covered by forests (San-Miguel-Ayanz et al. 2011; Zajączkowski et al. 2014), which locates Poland among the countries with substantial forest cover in the region (San-Miguel-Ayanz et al. 2011). Polish forests are largely dominated by coniferous forest habitats on sandy soils (51\%) and coniferous stands (approx. $70 \%$ of the forest area), with Pinus sylvestris L. (Scots pine) being the dominant tree species (approx. 60\%). Stands younger than 80 years cover approx. $70 \%$ of the forest area, with age class $41-60$ yrs accounting for as much as $26.0 \%$. Over $80 \%$ of forests in Poland is owned by the state (Zajączkowski et al. 2014).

Active forest fire prevention and suppression in Poland is carried both by the regular fire services and State Forest Administration (LP = Lasy Państwowe, State Forests National Forest Holding) - the main forest manager in the country, administrating $77.3 \%$ of the forest area (Zajączkowski et al. 2014), obliged to conduct forest fire prevention by the Forestry Act (1991).

In Białowieża Forest, one of the best preserved lowland forest ecosystems in temperate Europe (Faliński 1986; Peterken 1996) fires happen at present rather incidental, alike in the rest of Poland are effectively controlled and thereby affect very small areas (ca. 0.5 ha) (E. Zin and M. Niklasson, unpubl.). However numerous stands with fire scarred trees, stumps and snags, especially in the conifer dominated areas, can be found (e.g. Faliński 1986); indicating substantial fire presence in the past. This has been also confirmed by the first tree ring fire history reconstruction in that area (Niklasson et al. 2010).

To conclude on past and present fire regimes in temperate forest zone of lowland Central Europe we used Poland as a case study and applied both: (1) literature review (including actual fire inventory reports throughout the last decades) on current data concerning present fire activity in the country and (2) tree ring fire history record from two locations in Białowieża Forest, obtained by dendroecological analyses of tree ring samples from Pinus sylvestris, spanning over the period 1650-2010.

\section{Methods}

To achieve data on the present forest fire activity in Poland we did literature review. Additionally, selected actual fire inventory reports throughout the last decades were reviewed in the National Information System on Forest Fires database (available online at https:// bazapozarow.ibles.pl/ ibl_ppoz/faces/index.jsp). To summarize data on the annual number of forest fires, burnt area in forest fires and mean area burned in a single forest fire in Poland in 1990-2013, we used the following publications: Szczygieł and Piwnicki (2011); Piwnicki and Szczygieł (2011, 2012); Zajączkowski et al. (2014). The first one may be found in Schmuck et al. (2011). The three latter ones are available online at http://www.gios.gov.pl/monlas/raporty.html (Annual Reports: 2011, 2012) and at http://www.lasy.gov.pl/informacje/publikacje/ informacje-statystyczne-i-raporty/raport-o-stanielasow/raport-o-stanie-lasow-2013/view (Annual Report: 2013), respectively.

Tree ring fire history data from two locations in Białowieża Forest were obtained by dendroecological analyses of wood samples from Pinus sylvestris, spanning over the period 1650-2010. Exact fire dates were identified by cross dating of fire scars according to the standard dendrochronological techniques. Details on field and laboratory procedures are given in Niklasson et al. (2010). 


\section{Results and discussion}

\section{Present-day forest fire activity in Poland}

Poland is one of the countries with the highest annual number of forest fires in Central-Eastern Europe (Szczygieł et al. 2009a), with as many as 9-10 000 individual fire events per year, however of relatively limited size, with $0.5-0.95$ ha being mean values of area burned in a single forest fire in the recent decades (Tab. 1).

Although most of the burnt area occurs nowadays in the Mediterranean part of the European continent (Schmuck et al. 2011), Poland still has accounted for as much as $60 \%$ of all forest fires in CentralEastern European countries in 1999-2001, with as many as approx. 240.5 th. fires which burned approx. 465 th. ha. In that period larger burnt area has been noted only once, in 1996, when the highest value has been recorded in the Ukraine (Szczygieł et al. 2009a). In the recent past (1990-2013) the highest number of forest fires in Poland occurred in 2003, with the record value of 17088 fires. The largest area (43 755) burned in Polish forest fires in 1992 (Tab. 1). This has been a year with a disastrous fire situation (Szczygieł et al. 2008, 2009a), when the two largest, catastrophic forest fires in Poland in the recent history have occurred. In the Potrzebowice Forest District in north-western Poland more than 5000 ha have burnt, whereas the Rudy Raciborskie fire in Upper Silesia (southwestern Poland), being the largest forest fire in the country since 1948, has damaged over 9000 ha in Forest Districts: Rudy Raciborskie, Rudziniec and Kędzierzyn (Hawryś et al. 1998, 2004; Dobrowolska 2008; Szczygieł et al. 2008).

As weather conditions and litter humidity are the main drivers of the fire risk in Poland (Ubysz et al. 2006; Szczygieł et al. 2009b) the anticipated changes in temperature and precipitation patterns may considerably increase the burning hazard in the near future (Schelhaas et al. 2010). In fact, a significant rise in the forest fire activity in Poland has been already observed over the last decades due to the increasing trend in temperature and decreasing precipitation (Ubysz et al. 2006; Szczygieł et al. 2008). Furthermore, mild winters and shortening of the snow cover period have prolonged fire season (Szczygieł et al. 2008), that nowadays lasts from March-April to September (Ubysz et al. 2006; Piwnicki and Szczygieł 2011, 2012; Szczygieł and Piwnicki 2011; Zajączkowski et al. 2014). In 20112012 the highest forest fire risk has been recorded in April, May and June (Piwnicki and Szczygieł 2011, 2012), whereas in the last year in April and July (Zajączkowski et al. 2014). Nevertheless the effective fire suppression system in Poland may successfully prevent the increase in annually burnt forest area (Szczygieł et al. 2008). Mean area of a single forest fire in 1990-2013 was 0.93 ha (Tab. 1) - a value considerably lower than the average for earlier periods, given by Szczygieł et al. (2008): 3.25 ha in 1948-1950, 2.35 ha in 1951-1960, 1.78 ha in 1961-1970, 1.43 ha in 1971-1980 and 1.41 ha in 1981-1990. However, extreme weather conditions in certain years (like e.g. 2003) may still significantly increase the forest fire activity and hence the mean forest fire size (Tab. 1).

The main cause of fires in Poland are people as natural, lightning-ignited fires account for about $1 \%$ only. It has been also observed, that the number of forest fire outbreaks has been larger on holidays than on workdays (Ubysz and Szczygieł 2006). Arson cases have represented as much as approx. 40\% of forest fire causes throughout the recent past (Szczygieł et al. 2009a; Piwnicki and Szczygieł 2011, 2012; Szczygieł and Piwnicki 2011; Zajączkowski et al. 2014). Fire spreading from nonforest areas due to the burning of grasslands has been another important cause of forest fires in Poland (Rydzak and Trebecki 2009; Szczygieł et al. 2009a). This practice, although illegal according to Polish legislation (Nature Conservation Act 2004), has been traditionally aiming at improving grazing conditions by removal of old plant remains and post-fire fertilizing effect (Rydzak and Trebecki 2009; Szczygieł et al. 2009a). The decrease in number of fires caused by setting grasslands ablaze has been observed in the most recent years only (Rydzak and Trebecki 2009; Szczygieł and Piwnicki 2011; Zajączkowski et al. 2014), likely as an effect of educational campaigns by the State Forest 
Administration (Rydzak and Trebecki 2009; Szczygieł and Piwnicki 2011) and/or of people's concern for EU-subsidies, that could have been eventually withdrawn (Szczygieł et al. 2009a).

Table 1. Data on forest fires in Poland in 1990-2013 (Sources: Piwnicki and Szczygiet 2011, 2012; Szczygiet and Piwnicki 2011; Zajaczkowski et al. 2014).

\begin{tabular}{cccc}
\hline Year & No of forest fires & Burnt area (ha) & Mean fire area (ha) \\
\hline 1990 & 5756 & 7341 & 1.28 \\
1991 & 3528 & 2567 & 0.73 \\
1992 & 11858 & 43755 & 3.69 \\
1993 & 8821 & 8290 & 0.94 \\
1994 & 10710 & 9171 & 0.86 \\
1995 & 7681 & 5306 & 0.69 \\
1996 & 7924 & 14120 & 1.78 \\
1997 & 6818 & 6598 & 0.97 \\
1998 & 6166 & 4019 & 0.65 \\
1999 & 9820 & 8307 & 0.85 \\
2000 & 12428 & 7013 & 0.56 \\
2001 & 4480 & 3429 & 0.77 \\
2002 & 10101 & 5593 & 0.55 \\
2003 & 17088 & 28554 & 1.67 \\
2004 & 7219 & 4338 & 0.60 \\
2005 & 12803 & 7387 & 0.58 \\
2006 & 11828 & 5912 & 0.50 \\
2007 & 8302 & 2841 & 0.34 \\
2008 & 9090 & 3027 & 0.33 \\
2009 & 9161 & 4400 & 0.48 \\
2010 & 4680 & 2126 & 0.45 \\
2011 & 9220 & 2850 & 0.31 \\
2012 & 9265 & 7235 & 0.78 \\
2013 & 4883 & 1289 & 0.26
\end{tabular}

Mean values for the periods

\begin{tabular}{lccc}
$\mathbf{1 9 9 0 - 2 0 1 3}$ & $\mathbf{8 7 3 5}$ & $\mathbf{8 1 4 5}$ & $\mathbf{0 . 9 3}$ \\
$1990-1999$ & 7908 & 10947 & 1.38 \\
$2000-2013$ & 9325 & 6142 & 0.66 \\
& & & \\
$1999-2003$ & 10783 & 10579 & 0.98 \\
$2004-2008$ & 9848 & 4701 & 0.48 \\
$2009-2013$ & 7442 & 3580 & 0.48 \\
\hline
\end{tabular}

Fire prevention together with creating and maintaining fire protection infrastructure are obligatory tasks of the Polish State Forest Administration (LP = Lasy Państwowe, State Forests National Forest Holding), as defined by the Forestry Act (1991). Current fire prevention and suppression measures applied by the State Forest Administration, besides education activities for the public, include construction of fuel- and fire breaks, silvicultural operations, fire observation system, communication 
and alarm network, water supply points and professional fire suppression equipment (Szczygieł and Piwnicki 2011). All that has amounted to the total fire protection cost (incurred by the State Forest Administration) of 294 mill PLN (approx. 71 mill EUR) in 2003-2004 (Szczygiel et al. 2007) and of 63 mill PLN (approx. 15.2 mill EUR) in 2010 only (Szczygieł and Piwnicki 2011). According to the Polish law State Forest Administration is not obliged to conduct active fire suppression. Nevertheless it belongs to its important activities. In 2003-2004 fire suppression carried out by the State Forest Administration has accounted for $17.2 \%$ of the total fire protection cost incurred, corresponding to the cost of approx. 8-10 mill PLN (approx. 1.9-2.4 mill EUR) annually. As many as 9\% of all forest fires in that period have been supressed by the employees of the State Forest Administration alone, with no fire brigades involved (Szczygieł et al. 2007).

At present there is no prescribed burning practice in Polish forests as it is legally restricted (e.g. Forestry Act 1991; Nature Conservation Act 2004). In the other neighbouring countries in the temperate Europe fire use is still practiced at the experimental level only, for nature conservation and landscape management purposes (Goldammer and Bruce 2004).

\section{Historical forest fire record from Bialowieża}

The first tree ring fire history records from two locations in Białowieża Forest evidenced frequent fires in Pinus sylvestris-dominated stands during the 17 th up to early 19 th centuries, with dramatic decrease in fire presence over the last $150+$ years, most likely linked to changes in human fire use and forest management (Niklasson et al. 2010; Zin et al., unpubl.).

Despite the considerable fire occurence in Central-Eastern Europe nowadays (e.g. Szczygieł et al. 2009a; Schmuck et al. 2011), there are hardly any annually resolved data on fire activity in temperate European forests spanning over time periods longer than the 20th and the 21st centuries (cf. Niklasson et al. 2010). As main reasons for the lack of such research in that region Niklasson et al. (2010) gave both the traditional perspective on fire as less important disturbance agent in the vegetation dynamics of this biome (e.g. Ellenberg 1988; Vera 2000; Timbal et al. 2005) and the paucity of old-growth woodlands enabling dendrochronological analyses spanning over several centuries, mainly linked to the long history of forest use and management throughout this part of the European continent (e.g. Pyne 1997; Farrell et al. 2000).

Białowieża Forest however, a large woodland in the borderland between north-eastern Poland and western Belarus, offers an extraordinary value for dendroecological studies. Thanks to its status as a royal hunting area since the early 1400s (Samojlik 2007) it withstood deforestation and commercial timber exploitation that made thousands of hectares of old-growth woodlands all over the continent disappear and survived until today as one of the best preserved temperate lowland deciduous and mixed forests in Europe (Faliński 1986; Peterken 1996). Considering dendrochronological recunstructions, Białowieża Forest is most likely unique among other European lowland forests. Old-growth forest stands with deadwood continuity and numerous ancient, large-size trees that are still present in that area (Faliński 1986; Sokołowski 2004) deliver annually resolved tree ring record of past stand and forest dynamics.

The first tree ring fire history record from a site located in the Polish part of Białowieża Forest (Niklasson et al. 2010), being to our knowledge also the first dendrochronological fire history reconstruction from the temperate forests of lowland Central Europe, has evidenced fire as a factor of major importance for the past forest dynamics. It has been proven that historical fires were recurring at very short intervals (approx. 10 years on average) over the last 350+ years (1650-2007), which favoured Pinus sylvestris-dominated forest. However, significant temporal changes in the past fire frequencies have been recorded at the end of the 18th century, when fire intervals have significantly increased. The complete cessation of fire occurrence has been documented since 1920s. This change in historical fire regime has resulted in a remarkable shift in tree establishment patterns, towards the dominance of fire-sensitive, shade-tolerant Norway spruce (Picea abies (L.) Karst.) (Niklasson et al. 
2010) - a phenomenon described also in boreal Europe (e.g. Linder 1998; Wallenius et al. 2004). Furthermore, substantial human impact on the reconstructed fire regime has been suggested (Niklasson et al. 2010), alike in other studies from Northern European locations (e.g. Niklasson and Granström 2000; Groven and Niklasson 2005; Storaunet et al. 2013).

Interestingly, the second tree ring fire history record from Białowieża Forest, coming from a study site located in the Belarusian section of that area (Zin et al., unpubl.), brought similar information on the historical forest fire activity over the analogous period. That site, although separated in space, evidenced comparably high fire frequency between 1650 s and the first decades of the 1800 s, when the onset of fire decline appeared. Similarly to the Polish location, no fires were recorded since the first decades of the 20th century (Zin et al., unpubl.).

\section{Conclusions}

We conclude that there is a large need for fire history and fire ecology studies in Central Europe due to high population density and strong dominance of flammable conifers in forests of that region. Extended knowledge about past disturbance dynamics and reference conditions may be essential for future sustainable forest management and nature conservation throughout this part of European continent.

\section{References}

Badeck F-W, Lasch P, Hauf Y, Rock J , Suckow F, Thonicke K (2003) Steigendes klimatisches Waldbrandrisiko. Allgemeine Forst Zeitschrift für Wald und Forstwirtschaft 59, 90-92.

Bradshaw RHW, Tolonen K, Tolonen M (1997) Holocene records of fire from the boreal and temperate zones of Europe. In 'Sediment Records of Biomass Burning and Global Change'. (Eds JS Clark, H Cachier, JG Goldammer, B Stocks) pp. 347-365. (Springer Verlag: Berlin-Heidelberg).

Dobrowolska D (2008) Odnowienie naturalne na powierzchniach uszkodzonych przez pożar w Nadleśnictwie Rudy Raciborskie. Leśne Prace Badawcze 69(3), 255-264.

Ellenberg H (1988) 'Vegetation Ecology of Central Europe'. (Cambridge University Press: Cambridge)

Faliński JB (2001) Fires in the long-term dynamics of pine subcontinental forests. In 'Coniferous forest vegetation - differentiation, dynamics and transformations', Seria Biologia Nr 69. (Eds A Brzeg, M Wojterska) pp. 131-170. (Wydawnictwo Naukowe UAM: Poznań)

Faliński JB (1986) 'Vegetation Dynamics in Temperate Lowland Primeval Forest. Ecological Studies in Białowieża Forest'. (Dr W. Junk Publishers: Dordrecht)

Farrell EP, Führer E, Ryan D, Andersson F, Hüttl R, Piussi P (2000) European forest ecosystems: building the future on the legacy of the past. Forest Ecology and Management 132, 5-20.

Forestry Act (1991) Ustawa z dnia 28 września 1991 r. o lasach (Dz.U. 1991 Nr 101 poz. 444, ze zm.). Kancelaria Sejmu (Warszawa)

Goldammer JG, Bruce M (2004) The use of prescribed fire in the land management of Western and Baltic Europe: An overview. International Forest Fire News 30, 2-13.

Groven R, Niklasson M (2005) Anthropogenic impact on past and present fire regimes in a boreal forest landscape of southeastern Norway. Canadian Journal of Forest Research 35, 2719-2726.

GUS 2014. Polska w liczbach. Główny Urząd Statystyczny, Zakład Wydawnictw Statystycznych. (Warszawa) Available at http://www.stat.gov.pl [Verified 13 July 2014]

Hannon GE, Bradshaw R, Emborg J (2000) 6000 years of forest dynamics in Suserup Skov, a seminatural Danish woodland. Global Ecology and Biogeography 9, 101-114.

Hawryś Z, Zwoliński J, Kwapis Z, Wałecka M (2004) Rozwój sosny zwyczajnej na terenie pożarzysk leśnych z 1992 roku w Nadleśnictwach Rudy Raciborskie i Potrzebowice. Leśne Prace Badawcze 2, 7-20. 
Hawryś Z, Zwoliński J, Matuszczyk I, Olszewska G, Zwolińska B, Batko B (1998) Zmiany i odbudowa ekosystemów leśnych zniszczonych przez pożar na przykładzie wielkoobszarowego pożarzyska w lasach Rudzko-Rudziniecko-Kętrzyńskich. Postępy Techniki Leśnej 67, 33-40.

Hille M (2006) Fire Ecology of Scots Pine in Northwest Europe. Wageningen University, Ph.D. thesis. (Wageningen)

Linder P (1998) Structural changes in two virgin Boreal forest stands in central Sweden over 72 years. Scandinavian Journal of Forest Research 13, 451-461.

Nature Conservation Act (2004) Ustawa z dnia 16 kwietnia 2004 r. o ochronie przyrody (Dz.U. 2004 nr 92 poz. 880). Kancelaria Sejmu (Warszawa)

Niklasson M, Granström A (2000) Numbers and sizes of fires: long-term spatially explicit fire history in a Swedish boreal landscape. Ecology 81, 1484-1499.

Niklasson M, Zin E, Zielonka T, Feijen M, Korczyk AF, Churski M, Samojlik T, Jędrzejewska B, Gutowski JM, Brzeziecki B (2010) A 350-year tree-ring fire record from Białowieża Primeval Forest, Poland: implications for Central European lowland fire history. Journal of Ecology 98, 1319-1329.

Peterken GF (1996) 'Natural Woodland: Ecology and Conservation in Northern Temperate Regions'. (Cambridge University Press: Cambridge)

Piwnicki J, Szczygieł R (2011) Pożary lasów. In Raport 2011. Stan zdrowotny lasów Polski w roku 2011. Monitoring lasów w Polsce. Państwowy Monitoring Środowiska, Instytut Badawczy Leśnictwa - Główny Inspektorat Ochrony Środowiska, Annual Report 2011, pp. 39-41. Available at http://www.gios.gov.pl/monlas/raporty/raport_2011/01.html [Verified 13 July 2014]

Piwnicki J, Szczygieł R (2012) Pożary lasów. In Raport 2012. Stan zdrowotny lasów Polski w roku 2012. Monitoring lasów w Polsce. Państwowy Monitoring Środowiska, Instytut Badawczy Leśnictwa - Główny Inspektorat Ochrony Środowiska, Annual Report 2012, pp. 38-39. Available at http://www.gios.gov.pl/monlas/raporty/raport_2012/12.html [Verified 13 July 2014]

Pyne SJ (1997) 'Vestal Fire. An Environmental History, Told through Fire, of Europe and Europe's Encounter with the World'. (University of Washington Press: Seattle)

Rösch M (2000) Long-term human impact as registered in an upland pollen profile from the southern Black Forest, southwestern Germany. Vegetation History and Archaeobotany 9, 205-218.

Rydzak W, Trebecki J (2009) Modes of Wildland Fire Fighting through Educational Campaign in Transition Countries in Europe: Case Study of Poland. Journal of Forestry 107(8), 419-424.

Samojlik T (2007) Antropogenne przemiany środowiska Puszczy Białowieskiej do końca XVIII wieku. Mammal Research Institute, Polish Academy of Sciences - Jagiellonian University, Ph.D. thesis. (Białowieża - Kraków)

San-Miguel-Ayanz J, Ståhl G, Vidal C, Bonhomme C, Cienciala E, Korhonen K, Lanz A, Schadauer K (2011) Criterion 1: Maintenance and Appropriate Enhancement of Forest Resources and their Contribution to Global Carbon Cycles. In 'FOREST EUROPE, UNECE and FAO 2011: State of Europe's Forests 2011. Status and Trends in Sustainable Forest Management in Europe' pp. 17-27. (Ministerial Conference on the Protection of Forests in Europe: Oslo)

Schelhaas MJ, Hengeveld G, Moriondo M, Reinds GJ, Kundzewicz ZW, ter Maat H, Bindi, M (2010) Assessing risk and adaptation options to fires and windstorms in European forestry. Mitigation and Adaptation Strategies for Global Change 15(7), 681-701.

Schelhaas MJ, Nabuurs GJ, Schuck A (2003) Natural disturbances in the European forests in the 19th and 20th centuries. Global Change Biology 9, 1620-1633.

Schmuck G, San-Miguel-Ayanz J, Camia A, Durrant T, Santos de Oliveira S, Boca R, Whitmore C, Giovando C, Libertá G, Corti P, Schulte E (2011) Forest Fires in Europe 2010. European Commission, Joint Research Centre - Institute for Environment and Sustainability, JRC Scientific and Technical Reports, Report No 11. (Luxembourg, Publications Office of the European Union)

Sokołowski AW (2004) 'Lasy Puszczy Białowieskiej’. (Centrum Informacyjne Lasów Państwowych: Warszawa). 
Storaunet KO, Rolstad J, Toeneiet M, Blanck Y (2013) Strong anthropogenic signals in historic forest fire regime: a detailed spatiotemporal case study from south-central Norway. Canadian Journal of Forest Research 43, 836-845.

Szczygieł R, Piwnicki J (2011) Country Report: Poland. In Forest Fires in Europe 2010 (Eds. G Schmuck, J San-Miguel-Ayanz, A Camia, T Durrant, S Santos de Oliveira, R Boca, C Whitmore, C Giovando, G Libertá, P Corti, E Schulte) pp. 44-48. European Commission, Joint Research Centre - Institute for Environment and Sustainability, JRC Scientific and Technical Reports, Report No 11. (Luxembourg: Publications Office of the European Union)

Szczygieł R, Piwnicki J, Ubysz B (2007) Analiza ekonomiczna funkcjonowania ochrony przeciwpożarowej lasu w Lasach Państwowych. Leśne Prace Badawcze 1, $27-50$.

Szczygieł R, Ubysz B, Piwnicki J (2008) Wpływ zmian klimatycznych na kształtowanie się zagrożenia pożarowego lasów w Polsce. Leśne Prace Badawcze 69(1), 67-72.

Szczygieł R, Ubysz B, Zawiła-Niedźwiecki T (2009a) Spatial and temporal trends in distribution of forest fires in Central and Eastern Europe. In 'Wildland Fires and Air Pollution' (Eds A Bytnerowicz, M Arbaugh, A Riebau, C Andersen) pp. 233-245. (Elsevier: Amsterdam - Oxford)

Szczygieł R, Ubysz B, Kwiatkowski M, Piwnicki J (2009b) Klasyfikacja zagrożenia pożarowego lasów Polski. Leśne Prace Badawcze 70(2), 131-141.

Timbal J, Bonneau M, Landmann G, Trouvilliez J, Bouhot-Delduc L (2005) European non-boreal conifer forests. In 'Ecosystems of the World. Coniferous Forests' (Ed F Andersson) pp. 131-162. (Elsevier: Amsterdam - San Diego - Oxford - London)

Ubysz B, Szczygiel R (2002) Fire Situation in Poland. International Forest Fire News 27, 38-64.

Ubysz B, Szczygieł R (2006) A study on the natural and social causes of forest fires in Poland. Forest Ecology and Management 234S, S13.

Ubysz B, Szczygieł R, Piwnicki J (2006) Analysis of the trends in the forest fire risk for recent years in Poland against the background of long-term trends. Forest Ecology and Management 234S, S248.

Vera F (2000) ‘Grazing Ecology and Forest History'. (CABI Publishing: Wallingford)

Wallenius TH, Kuuluvainen T, Vanha-Majamaa I (2004) Fire history in relation to site type and vegetation in Vienansalo wilderness in eastern Fennoscandia, Russia. Canadian Journal of Forest Research 34, 1400-1409.

Zajączkowski G, Jabłoński M, Jabłoński T, Małecka M, Kowalska A, Małachowska J, Piwnicki J (2014) Raport o stanie lasów w Polsce 2013. Państwowe Gospodarstwo Leśne Lasy Państwowe, Dyrekcja Generalna Lasów Państwowych, Centrum Informacyjne Lasów Państwowych, Annual Report 2013. (Warszawa) Available at http://www.lasy.gov.pl/informacje/ publikacje/informacjestatystyczne-i-raporty/raport-o-stanie-lasow/raport-o-stanie-lasow-2013/view [Verified 14 July 2014] 